\title{
Comparative morphological and anatomical study of Primula macrocalix Bge. and Primula sibthorpii Hoffm. leaves growing in Dagestan
}

\author{
Yulya Cheryatova ${ }^{1, *}$, and Galina Arnautova ${ }^{2}$ \\ ${ }^{1}$ Russian State Agrarian University - Moscow Agricultural Academy named after K.A. Timiryazev, \\ 127550, Moscow, Russian Federation \\ ${ }^{2}$ Dagestan Agricultural University named after M.M. Dzhambulatova, 367032 Makhachkala, Repub- \\ lic of Dagestan
}

\begin{abstract}
The article presents the results of morphological and anatomical leaves study of wild species Primula macrocalix Bge. and Primula sibthorpii Hoffm. promising for horticulture growing in Dagestan. Anatomic and diagnostic traits of plant leaves, allowing their interspecies identification in the virginile period were revealed. It was found that the upper epiderm cells of $P$. sibthorpii were distinguished by larger sizes compared to the epidermal cells of $P$. macrocalix. According to the obtained data, $P$. macrocalix and $P$. sibthorpii leaves are amphistomatal, stomatal apparatus is anomocytic. In early spring flowering $P$. sibthorpii, the number of stomata was almost 2 times that of the mid-spring $P$. macrocalix. The number of stomata on $P$. sibthorpii leaves was almost 2 times that of $P$. macrocalix. The stomatal index of $P$. macrocalix upper epiderm leaf amounted to $10.5 \pm 2.6 \%$ and the lower epiderm was 2 times higher $-22.4 \%$. The stomatal index of $P$. sibthorpii upper epiderm leaf amounted to $16.7 \pm 4.2 \%$ and the lower epiderm was $26.8 \pm 7.2 \%$. The index characteristic of primula species leaves showed an average variation coefficient, which is an indicator of their stomatographic traits' stability. The data obtained allow to reliably assess the authenticity of the primula species in question and can serve as a basis when compiling anatomical atlases of wild plants, as well as creating keys for determining the taxonomic species affiliation according to anatomical features.
\end{abstract}

\section{Introduction}

Primula L. (Primulaceae) genus is quite numerous - it has about 550 species distributed throughout the world, but mainly in temperate zones and in the Alpine mountain belt [1]. The modern development stage of research of primula species presents researchers with qualitatively new problems that require comparisons and generalizations. To study the systematic diversity, ecological and biological features of primula species, fundamental regional taxa studies on a natural and historical scale and geographical areas are required. This approach makes it possible to determine the place of the studied species in the system,

* Corresponding author: u.cheryatova@rgau-msha.ru 
to reveal the general regularities of their geographical differentiation. Since Primula genus is sufficiently large and polymorphic, the problem of interspecies plants' identification comes to the fore. This issue is especially critical when introducing wild primula species into the crop, as well as in conditions of industrial nursery [2].

Morphology traits of the lamina, its shape, the character of the leaf edge, the degree of leaf pubescence, as well as fibers types were traditionally used in the systematics of the Primula genus. However, for a long time the taxonomy of primula species caused controversy due to high morphological variability [3]. Therefore, the leaf anatomy can serve as an equally important diagnostic marker in the plant species comparative analysis, especially in the study of virginile plants [4]. The literary data analysis showed that currently there are no works on interspecies identification of primula species using anatomical methods of leaf diagnostics. As it is known, the epiderm structure and stomatal complexes morphology are constant for each plant species and are considered as significant taxonomic traits [5, 6, 7]. Similar data allows not only to conduct interspecies identification, but also to assess the species ecology [8 - 11].

Despite the increasing interest in Primula genus species, there is no information in domestic and foreign literature on microscopic structure of Primula macrocalix Bge. and Primula sibthorpii Hoffm promising for horticulture. Therefore, the aim of the study was to carry out a comparative analysis of anatomical diagnostic traits of $P$. macrocalix and $P$. sibthorpii leaves growing in the regions of Dagestan. Knowledge of $P$. macrocalix and $P$. sibthorpii leaf anatomy will allow to give the most complete and accurate species characteristic, supplementing these plants' morphology data. Moreover, P. macrocalix is a valuable medicinal plant, and the work results can serve in identifying the medicinal raw material of the leaves. The work was carried out in a timely manner since in recent years, the scientists' attention was attracted to the study of leaves micromorphology and glandular trichom chemistry of primula's medicinal species. Thus, it was established that in the primula species epiderm there is the greatest localization of biologically active substances (flavonoids, saponins, etc.), having a pronounced therapeutic value [12 - 14]. Considering the abovementioned, detailed study of the epiderm structure of $P$. macrocalix and $P$. sibthorpii leaves becomes even more relevant.

\section{Materials and Methods}

Experimental work was carried out at the Department of Botany, Breeding and Seed Production of Garden Plants of the Russian State Agrarian University - Moscow Agricultural Academy named after K.A. Timiryazev. Objects of study were plants $P$. macrocalix and P. sibthorpii collected in March 2020. P. macrocalix plants were obtained from the vicinity of Dubki settlement in Kazbek district of Dagestan, and P. sibthorpii from Rodnikovy village in Kaytagsky district of Dagestan. Due to geographical location, these areas of Dagestan are characterized by a high biodiversity degree of Primula genus species at both ecosystems, cenotic and population levels. Anatomical studies of leaves were carried out according to the methodology of Yu.S. Cheryatova [15]. Leaves from the middle part of the radical rosette were used in the study; temporary micropreparations of transversal and longitudinal sections were made of them. Histochemical reactions were carried out to identify xylogen in the walls' composition by a standard sample with phloroglucinol. The study was carried out on 10 plants of each species in 5-fold repetition using the Carl Zeiss Primo Star microscope, Carl Zeiss Microlmaging (Germany). Statistical processing of experimental data was carried out according to generally accepted methods. The study contained the following calculations: the arithmetic trait mean $(\bar{x})$, standard deviation $(S)$, selective error of the arithmetic mean $(S \bar{x})$ and variation coefficient $(C v)[16]$. 


\section{Results and Discussion}

P. macrocalix leaves are simple, sessile, oblong-ovate shape. The leaf edge is unclearly finely crenate-dentated; the lamina apex is blunt. The lamina is wrinkled, narrowed into a winged petiole. P. sibthorpii leaves are simple, sessile, reverse ovate. The leaf edge is finely crenate-dentated; the lamina apex is blunt. The lamina has a long wedge-shaped base peripterous into a winged petiole. The leaves of $P$. macrocalix and $P$. sibthorpii are covered with a cutinized single layer epiderm on both sides. Epidermal cell walls outline on the upper and lower side of $P$. macrocalix and $P$. sibthorpii leaves differs, they are less anfractuose on the upper side than on the lower (figure 1). P. sibthorpii upper epiderm cells differed in larger sizes compared to major epidermal cells of $P$. macrocalix.

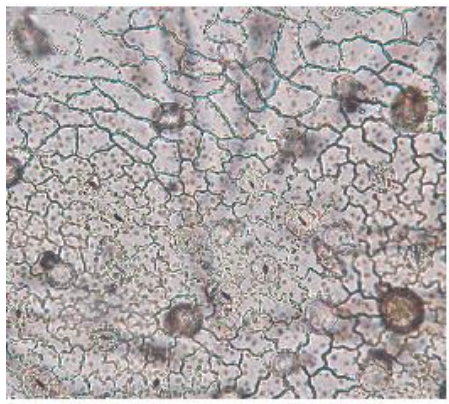

A

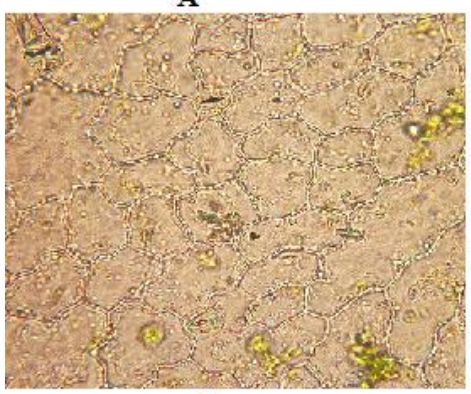

C

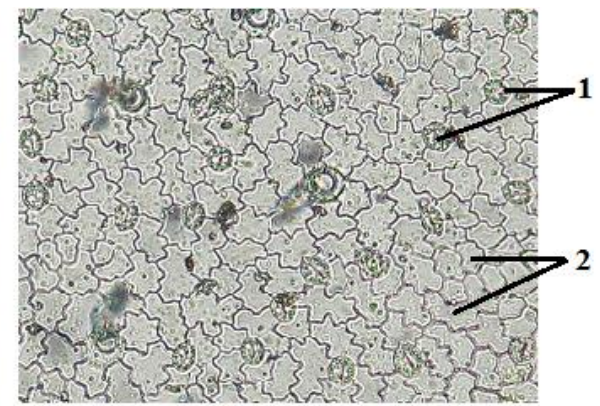

B

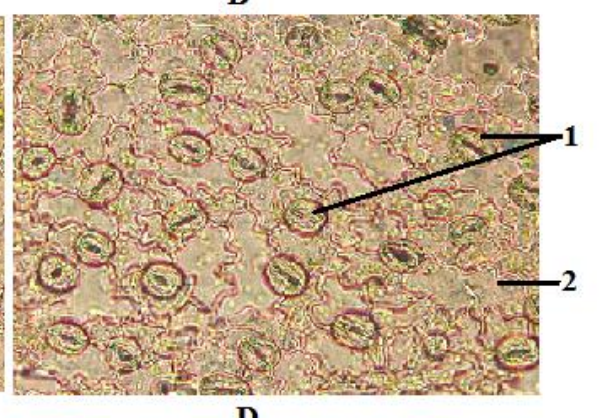

D

Fig. 1. Structure of P. macrocalix and P. sibthorpii lamina epiderm $(\times 100)$ : A $-P$. macrocalix upper epiderm; B - P. macrocalix lower epiderm; C - P. sibthorpii upper epiderm; D - P. sibthorpii lower epiderm

P. macrocalix lamina thickness amounted to $170.3 \pm 15.6 \mu \mathrm{m}$, and $P$. sibthorpii $132.8 \pm 19.1$ (table 1).

The variation in the radical rosette leaf thickness was average, indicating the morphological stability of this trait in the studied species. It was established that $P$. macrocalix and $P$. sibthorpii leaves are amphistomatal with stomata predominating on the underside of the leaf. The stomata are located on the same level with the main cells of the epiderm. It was experimentally estimated that the number of stomata per unit area $\left(1 \mathrm{~mm}^{2}\right)$ of the upper epiderm amounted to: $23.8 \pm 4.6$ in $P$. macrocalix; $P$. sibthorpii had much higher stomata number on a leaf $-40,5 \pm 7.2$. The number of stomata on the lower epiderm also differed significantly between the studied species: in P. macrocalix $-164.3 \pm 14.8$; and P. sibthorpii- $206.5 \pm 22.3$ (table 1.). 
Table 1. Morphometric characteristics of Primula macrocalix Bge. and

Primula sibthorpii Hoffm. leaves

\begin{tabular}{|c|c|c|c|c|c|c|c|c|}
\hline \multirow[b]{2}{*}{ 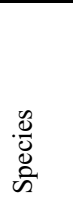 } & \multirow[b]{2}{*}{ 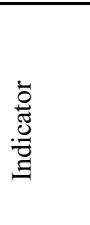 } & \multirow{2}{*}{$\begin{array}{c}\text { Leaf } \\
\text { thickness, } \\
\text { microns }\end{array}$} & \multicolumn{2}{|c|}{$\begin{array}{c}\text { Number of stomata } \\
\text { per } 1 \mathrm{~mm}^{2}\end{array}$} & \multicolumn{2}{|c|}{ Stomata size, $\mu \mathrm{m}$} & \multicolumn{2}{|c|}{$\begin{array}{c}\text { Stomatal } \\
\text { index }(S i), \%\end{array}$} \\
\hline & & & 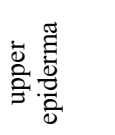 & 旁苞 & $\begin{array}{l}\text { 㺃 } \\
\text { 巴્ }\end{array}$ & $\frac{\frac{5}{5}}{\frac{0}{3}}$ & 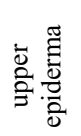 & 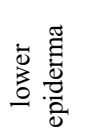 \\
\hline \multirow{2}{*}{ 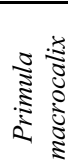 } & $\bar{x} \pm S \bar{x}$ & $170.3 \pm 15.6$ & $23.8 \pm 4.6$ & $\begin{array}{c}164.3 \pm \\
14.8 \\
\end{array}$ & $\begin{array}{c}26.6 \pm \\
7.4 \\
\end{array}$ & $\begin{array}{c}19.7 \pm \\
5.3\end{array}$ & $\begin{array}{c}10.5 \pm \\
2.6\end{array}$ & $\begin{array}{c}22.4 \pm \\
3.5\end{array}$ \\
\hline & $C v, \%$ & 17.2 & 16.5 & 18.2 & 30.7 & 25.8 & 15.2 & 11.4 \\
\hline \multirow{2}{*}{ 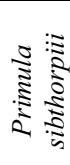 } & $\bar{x} \pm S \bar{x}$ & $132.8 \pm 19.1$ & $40.5 \pm 7.2$ & $\begin{array}{c}206.5 \pm \\
22.3 \\
\end{array}$ & $\begin{array}{c}23.5 \pm \\
6.2 \\
\end{array}$ & $\begin{array}{c}17.4 \pm \\
4.5 \\
\end{array}$ & $\begin{array}{c}16.7 \pm \\
4.2 \\
\end{array}$ & $\begin{array}{c}26.8 \pm \\
7.2 \\
\end{array}$ \\
\hline & $C v, \%$ & 22.5 & 20.9 & 24.8 & 26.9 & 34.2 & 12.6 & 19.3 \\
\hline
\end{tabular}

Dimensions of $P$. macrocalix and $P$. sibthorpii stomata varied widely and were characterized by a high variation coefficient. Obviously, this was associated with high rates of leaves' linear growth of spring-flowering plants and the presence of different stomata formation degrees. Stomatal leaves apparatus of $P$. macrocalix and $P$. sibthorpii anomocytic. A stoma is surrounded by $4-5$ cells similar in shape and size to the main epiderm cells. Guard stomata cells are fabaceous in the outline. Stomatal index of $P$. macrocalix upper leaf epiderm amounted to $10.5 \pm 2.6 \%$ and was 2 times higher for lower epiderm - 22.4\%. Stomatal index of upper epiderm leaf $P$. sibthorpii amounted to $16.7 \pm$ $4.2 \%$ and the lower epiderm $-26.8 \pm 7.2 \%$ (table 1 ). Thus, the index characteristic analysis of $P$. macrocalix and $P$. sibthorpii leaves showed an average variation coefficient, which is an indicator of stomatographic characteristics stability and may serve as a marker trait for interspecies identification.

$P$. macrocalix and $P$. sibthorpii leaves are medium pubescent with a mixed pubescence type. Trichomas were located more abundantly on the lower leaf side compared to the upper one. Leaf pubescence consisted of sessile simple single-row multicellular trichomes and capitated glandular fibers (figure 2).
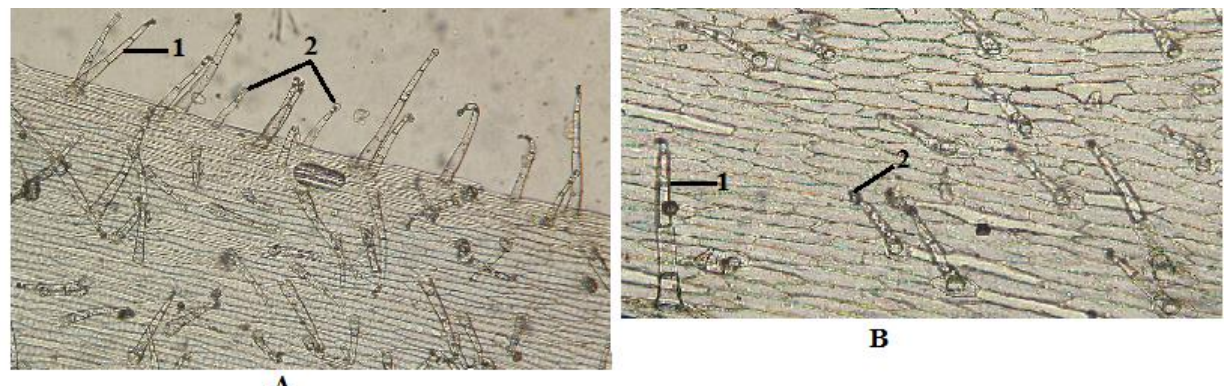

Fig. 2. Paradermal cut of $P$. macrocalix (A) and P. sibthorpii (B) lower epiderm along the middle leaf rib $(\times 200): 1$ - simple trichomes; 2 - capitated glandular fibers

Simple trichomes consisted of 2-4 cells. Capitated glandular fibers diffusely located throughout the lamina consisted of a three- or four-celled stalk and a single-celled globular end with or without contents. Only a small number of head fibers accumulated secretory 
content in the form of essential oil. Between the two epiderm layers there is a homogeneous 6-8-layer mesophyll, in which the leaf ribs were located. P. macrocalix and P. sibthorpii leaf nervation is pinnate-dictyodromous. All side ribs were represented by closed collateral bundles. In the main P. macrocalix rib a bicollateral bundle was formed in the shape of a semicircle, and in P. sibthorpii - horseshoe-shaped (figure 3). A distinctive feature of $P$. sibthorpii leaves was that the main rib bundle was associated with the upper side by sclerenchyma fibers.

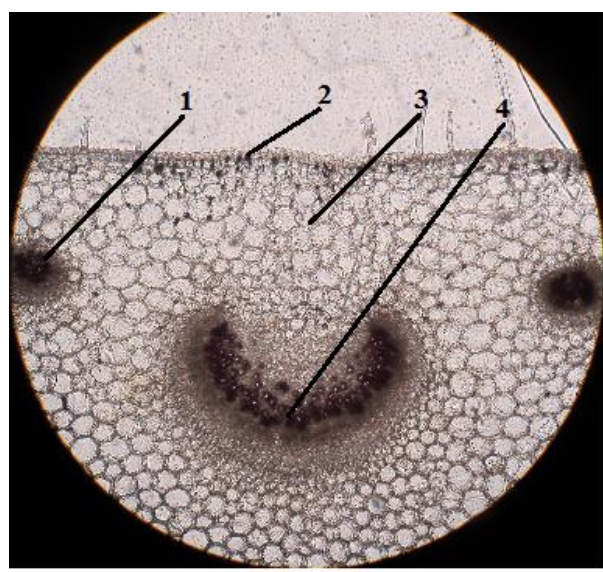

A

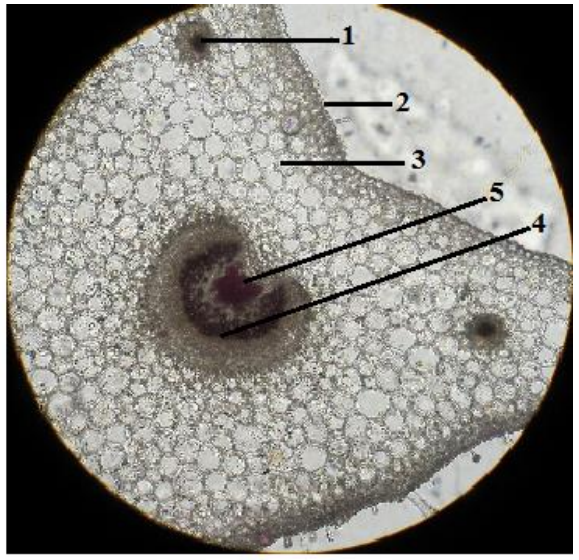

B

Fig. 3. Transverse leaf section in the middle rib segment of $P$. macrocalix (A) and P. sibthorpii (B) $(\times 200)$ : 1 - closed collateral bundle of the lateral rib; 2 - upper epiderm; 3 - mesophyll; 4 - bicollateral bundle of main rib; 5 - sclerenchyma fibers

In cross section, $P$. macrocalix leaf petiole is winged, triangular shaped (figure 4A). $P$. sibthorpii also has a winged petiole, but of an unambiguously triangular shape as it is completed by an oval in the lower part (figure $4 \mathrm{~B}$ ).

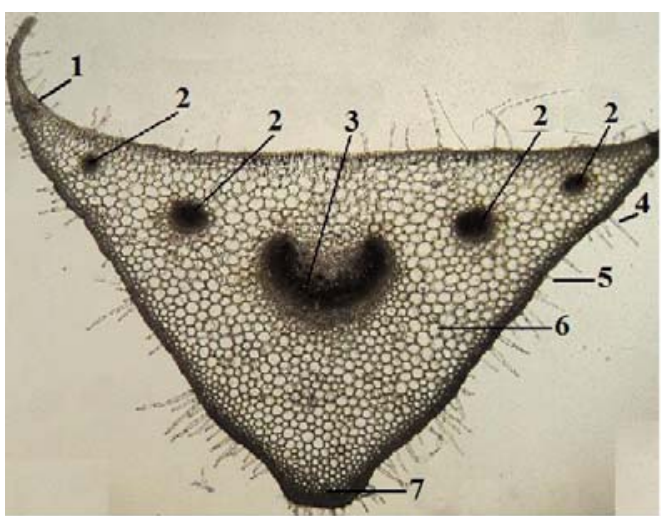

A

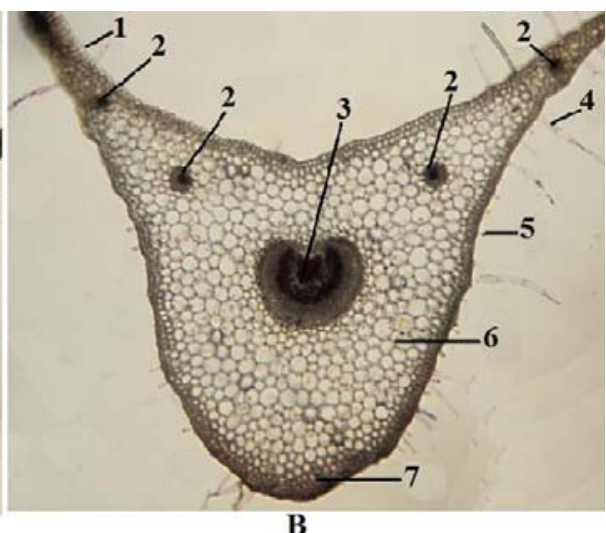

B

Fig. 4. Anatomical structure of the transverse section of the P. macrocalix (A) and $P$. sibthorpii leaf petiole (B) $(\times 100)$ : 1 - epiderm with cuticle; 2 - closed collateral bundle; 3 - bicollateral bundle; 4 simple trichomes; 5 - capitated fibers; 6 - chlorenchyma; 7 - angular collenchyme

On the petiole epiderm, simple multicellular fibers and capitated glandular trichomes were rarer compared to the lamina. Throughout the petiole, there was an angular collenchyme under the epiderm. The central petiole part is filled with chlorenchyma and conductive bundles. It has been determined that in P. macrocalix and $P$. 
sibthorpii leaves, a single central large bicollateral conductive bundle and four smaller closed collateral bundles in each lateral wing outgrowth was formed in the petiole.

\section{Conclusion}

The study found that the diagnosed microscopic traits of $P$. macrocalix and $P$. sibthorpii leaves are species-specific and can be used in conducting interspecies identification, as well as compiling anatomical atlases of wild plants. The anomocytic type of stomatal apparatus, as well as the nature of its location, shape and type of conductive leaf bundles are the most important traits of the primula species studied. The results of the study make it possible to conclude the stability of such an important indicator as the stomatal index of P. macrocalix and $P$. sibthorpii, which would certainly also be a reliable distinguishing inter-species trait. It should be noted that for the first time, the distinctive microscopic traits of $P$. macrocalix and $P$. sibthorpii leaf petioles have been determined by the method of comparative anatomy. It was found that a discrete - most evolutionarily advanced - type of vascular system was observed in the leaf petioles of the studied primula species; with it, individual bundles are immersed in the depth of the chlorenchyma. Thus, the anatomical leaf structure and established morphological types of the studied plant species' stomatal complexes can be used in solving problems of systematics of the Primula genus. To sum up, it should be noted that the practical significance of the work lies in the fact that the study results can serve as a basis for inter-specific identification of $P$. macrocalix and $P$. sibthorpii at plants' introduction. The obtained materials can also be used in breeding work in the selection of wild primula species.

\section{References}

1. M.A.-M. Astamirova, Genus Primula L. (Primulaceae Vent.) In the flora of the Terek Caucasus and Dagestan, 143 (2010)

2. L. Reynolds. Primulas for prairie gardens. Gardens West, 11, 50 (1997)

3. G. Fico, G. Rodondi, G. Flamini, Phytochemistry, 68, 1683 (2007)

4. Yu.S. Cheryatova, Ecosystem, 21, 85 (2020)

5. J.L. Croxdale, Am. J. Bot., 87, 1069 (2000)

6. B.J. Glover, J. Exp. Bot., 51, 497-505 (2000)

7. W. Beyschlag, J. Eckstein, Acta Oecol., 22, 161 (2001)

8. K.A. Mott, T.N. Buckley, Trends Plant Sci., 5, 258 (2000)

9. A.M. Hetherington, F.I. Woodward, Nature, 424, 901 (2003)

10. Z. Yunwei, Acta hortic. sinica, 33, 1365 (2006)

11. H. Shen, Y. Tang, H. Muraoka, J. Plant Res. 121,191(2008)

12. P.S Colombo, G. Flamini, M.S. Christodoulou, Phytochemistry, 98, 151 (2014)

13. P.S. Colombo, G. Flamini, G. Rodondi, Phytochemistry, 143, 132 (2017)

14. T.D. Bhutia, K.M. Valant-Vetschera, W. Adlassnig, Nat. Prod. Commun., 7, 1469 (2012)

15. Yu.S. Cheryatova, Anatomy of medicinal plants and medicinal plant raw materials, 95 (2010)

16. I.D. Sokolov, E.I. Sokolova, S.Yu. Naumov, Introduction to biometry: a training manual, 132 (2008) 